\title{
Seed Bank of Amorpha fruticosa L. on Some Ruderal
}

\section{Sites in Serbia}

\author{
Milan Blagojević ${ }^{1}$, Bojan Konstantinović ${ }^{1}$, Nataša Samardžić ${ }^{1}$, Aleksandar Kurjakov ${ }^{2}$ and Saša Orlović ${ }^{3}$ \\ 1. Department for Environmental and Plant Protection, Faculty of Agriculture, University of Novi Sad, Novi Sad 21000, Serbia \\ 2. Department of Pomology, Viticulture, Horticulture and Landscape Architecture, Faculty of Agriculture, University of Novi Sad, \\ Novi Sad 21000, Serbia
}

3. Institute of Lowland Forestry and Environment, University of Novi Sad, Novi Sad 21000, Serbia

\begin{abstract}
Amorpha fruticosa L. (Fabaceae), known as indigo bush, false indigo bush, false indigo and desert false indigo, is deciduous shrub (1-6 m tall). The woody weed species A. fruticosa has a high environmental adaptability and is present in different environmental conditions. In Vojvodina region (Northern Serbia), it is mostly present near irrigation channels and river banks, especially in alluvial or marshy areas. Since A. fruticosa is continually spreading near river banks, the aim of research was to determine seed bank composition near the Danube River. In 2014, soil sampling was performed at localities with high population of A. fruticosa (3-4 plants at age over two years and 10-14 plants at age 1-2 years). Soil samples were taken from two localities (Futog and Šangaj) with alluvial sandy soil and chernozem near the Danube River. Each sample was sieved through a system of copper sieves of various diameters. After the separation of seeds from samples, they were identified. Significant presence of $A$. fruticosa seeds $\left(1,914 \mathrm{seeds} / \mathrm{m}^{2}\right)$ was established in a layer of $0-10 \mathrm{~cm}$. In the same soil layer, the significant presence of seeds of Stellaria media (L.) Vill. and Urtica dioica L. were also established. Seeds of A. fruticosa were not found in soil layers 10-20 cm and 20-30 $\mathrm{cm}$. The invasive weed species A. fruticosa produces a large number of seeds in two cycles. The majority of the seeds stay in the upper soil layer, being dispersed by water (hydrochory).
\end{abstract}

Key words: Amorpha fruticosa L., soil seed bank, invasive species, seed dispersion.

\section{Introduction}

Amorpha fruticosa L. (Fabaceae), known as indigo bush, false indigo bush, false indigo and desert false indigo, is a bush with many gray bark shrubs. The purple flowers are in a spike-shaped inflorescences on the top of the branches. It blossoms in the end of May and June, and in a period of 20-25 d right after Acacia blossoms, when there is no other significant bee feed. It belongs to the honeybee weed species that in the last 5-10 years is also suitable for bee nectar collecting, which indicates a high distribution of this tree weed species in Vojvodina. A. fruticosa L. is suitable for reforestation of slopes after escarpments and landslides, because its roots bind the soil well. It is

Corresponding author: Bojan Konstantinović, associate professor, research fields: seed dormancy, weed seed bank and efficacy herbicides. E-mail: bojank@polj.uns.ac.rs. also used for windbreak belts, hedges and ornamental shrub in park, and can be cut every 3-4 years, since its sprouts restore quickly. The root system of this weed species is very strong. Acacia, a deciduous shrub, originates from the Middle and East part of the North America. In 1724, it was introduced to Europe as exotic and ornamental species. In many countries, such as Serbia, it represents one of the most dangerous invasive species. The height of $A$. fruticosa $\mathrm{L}$. (Fabaceae) bush is up to $6 \mathrm{~m}$, and sometimes shaped as a tree with thin straight branches. Its shoots are covered with yellowish-green or dark hairs. The leaves are odd-pinnate, up to $30 \mathrm{~cm}$ long and with 5-10 pairs of leaves that are ovate-elliptic to elongated, almost lanceolate up to $4 \mathrm{~cm}$ long and $1.8 \mathrm{~cm}$ wide. On the face side, it is green, mostly bare; on the bottom side, it is light gray-green or bare. 
Inflorescences are clustered, dense, erect, hairy and long up to $15 \mathrm{~cm}$. Calyx is tubular bell-shaped, and calyx teeth is short and unequal. The flower is dark purple. A pillar-like stalk is bare or hairy. The fruit is bent, 8-9 mm long, warty glandiform and does not open but ruptures later; the fruit contains also about 3 mm elongated seed. During germination, "seed" (the seedpod) first develops the root from the radicle, out of which lateral roots are grown; they fasten themselves into the soil to absorb water and minerals [1]. On marshes, A. fruticosa stops the development of the existing vegetation [2]. This weed species has also been characterized as invasive weed species of the Central Europe [3].

A. fruticosa L. is usually found in swamps, on the canals and ponds, as well as in flooded forests [4] or slightly overgrown banks, reeds and highly halophyte habitats [5]. It grows well on dams, roads and railways. It is used for reforestation of salt spring and it is important for beekeeping. In Serbia, it has been cultivated for a long time in nature; it is often found sub-spontaneous. It is domesticated in the Central and Eastern part of North America, throughout Eastern Canada and Northern Mexico. It is often grown as an ornamental plant. Weed seed bank affects the propagation of both annual [6] and perennial weed species [7], which affects the spread of the weed community over the years. Perennial agrophytocoenoses, such as vineyards, may be less likely to undergo dramatic changes in the weed seed bank in comparison to annual agrophytocoenoses, due to the lack of crop rotation. Reduced soil tillage results from the use of fewer mineral nutrients. The frequency of weed occurrence is limited due to the danger of soil compacting in moist winter season. All of this can affect weed occurrence and seed bank composition [8]. On ruderal habitats, weed species $A$. fruticosa $\mathrm{L}$. is successfully controlled by the following herbicides: glyphosate (Glifosat-Zorka, Agro quarto, Blade 48-SL, Glifeksol SL-360, Agroglifosat eco, Bingo-480, Fozat-480, Limitator extra, Titan) and triclopyr triethylamine (Garlon 4 A) [9]. Biological weed invasion is a great danger for preservation of biological diversity, because it can cause the extinction of indigenous species and change the functions of ecosystem [10]. Among numerous factors, invasion success depends on biological characteristics of the attackers as well as the availability of habitat resources [11]. Marshy areas are especially susceptible to invasion due to the highly changeable habitat regime [12], and therefore seed is easily disseminated by water [13]. Invasive marsh plants have significant effect on habitat structure and biodiversity [14], but it should be kept in mind that marshes are less prone to changes, at least in sense of dramatic ecosystem transformations [15].

\section{Materials and Methods}

Soil sampling at localities Futog and Šangaj with the developed population of A. fruticosa L. in the coastal zone of the Danube has been done. Sites are at the junction to 15-20 years old poplar plantation, which were systematically planted by "Vojvodinašume" along the Danube. At the selected localities of approximately 10 ha, a soil sampling was done on the depth of $0-30 \mathrm{~cm}$ with 10 diagonal replications on the selected area. On the examined localities, soil types are alluvial sandy soil and chernozem on the sand. Sampling was done by a probe in $4.5 \mathrm{~cm}$ diameter. Each of the 10 samples was taken at the depth of 0-10, 10-20 and 20-30 cm. Every sample from one of the three depths contained about 3 $\mathrm{kg}$ of the soil, which was sieved through a series of copper sieves of $0.25 \mathrm{~mm}$ in diameter. This was followed by the separation of weed seeds samples from impurities of plant and any other material, after which the seed was determined. Determination and numbering of the weed species seeds were performed using a microscope as well as methods described by Ref. [16]. Data processing was performed by the method of Refs. [17, 18].

Determined weed seeds were disinfected in $0.1 \%$ 
fungicide solution based on the active substance mancozeb, and then placed in a climate chamber for seed germination under controlled conditions. The parameters of air-conditioning chamber were set at $25^{\circ} \mathrm{C} 12 \mathrm{~h}$ under light and $18{ }^{\circ} \mathrm{C} 12 \mathrm{~h}$ without light; the air humidity was $65 \%$. Petri dishes were $100 \mathrm{~mm}$ $\times 90 \mathrm{~mm}$ and covered by polyethylene leaves in order to avoid evaporation. The check of germination of determined seeds was done in every $2 \mathrm{~d}$. The seeds which had a radical were considered as germinated seeds. After $28 \mathrm{~d}$, measurements of the part above the ground and under the ground of the seedlings were performed for all germinated seeds.

Numbers of seeds for each weed species per depth of soil sampling were accomplished by computer data processing. The total numbers of seeds for each weed species were calculated in 10 replications. The result was used to calculate the numbers of seeds $/ \mathrm{m}^{2}$, based on the Eq. (1):

$$
\frac{1.63}{X}=\frac{130}{Y}
$$

where,

$X=$ numbers of seeds in 10 replications;

$Y=$ numbers of seeds $/ \mathrm{m}^{2}$;

1.63 = mass of soil samples for 10 replications to the depth of $0-10 \mathrm{~cm}$, where the soil density is $1.3 \mathrm{~g} / \mathrm{cm}^{3}$, in $\mathrm{kg}$;

$130=$ mass of the soil $/ \mathrm{m}^{2}$ to depth of $0-10 \mathrm{~cm}$, in $\mathrm{kg}$.

\section{Results and Discussion}

The systems with lower-scale cultivation tend to have considerably more seeds in the surface layer soil than the intensively cultivated systems [19]. In weed seed bank at locality Futog, 11 weed species were identified: Amorpha fruticosa, Stellaria media, Amaranthus retroflexus, Urtica dioica, Brassica rapa, Mentha arvensis, Solanum nigrum, Portulaca oleracea, Trifolium repens, Setaria glauca and Rumex crispus. In the first two layers from $0-10 \mathrm{~cm}$ and 10-20 cm, most of the weed species seeds were determined, and A. fruticosa L. seed was found only in the first two layers. In the first layer, 1,914 seeds $/ \mathrm{m}^{2}$ of weed species A. fruticosa L. were identified (Fig. 1). On sampled locality Futog, the average established numbers of $A$. fruticosa plants per square meter were 3.92 plants $/ \mathrm{m}^{2}$ aged older than two years and 10.23 plants $/ \mathrm{m}^{2}$ aged of 1-2 years.

Standard deviation shows the average error of the number of seeds of each weed species from the mean value. The coefficient of variation indicates the percentage variation of the number of seeds in various soil depths. The highest average deviation shows species

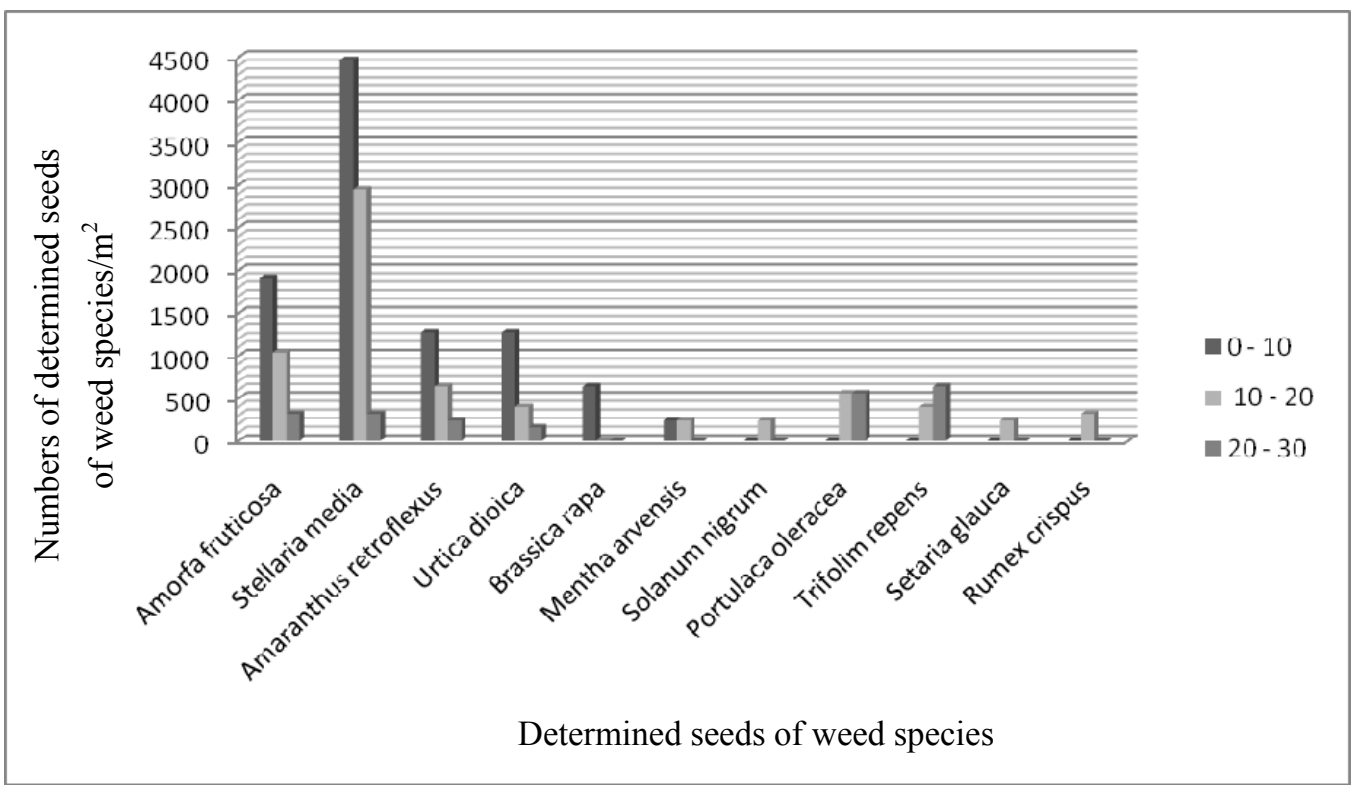

Fig. 1 The total numbers of weed species seeds $/ \mathrm{m}^{2}$ at locality Futog. 
Brassica rapa, Solanum nigrum, Setaria glauca and Rumex crispus, while the lowest deviation shows weed species Amaranthus retroflexus. Looking at total numbers of identified seeds of weed species, it can be seen that a reduction in the numbers of seeds occurs with increasing depth. In percentage, total germination of the identified seeds is between $1.57 \%$ for weed Setaria glauca and the highest germination of $11.23 \%$ in seed of weed species Portulaca oleracea. In the following vegetation period, numbers of potential plants from the total numbers of $A$. fruticosa L. seeds $\left(3,270\right.$ seeds $\left./ \mathrm{m}^{2}\right)$ was 122 plants $/ \mathrm{m}^{2}$; this was established on the basis of germination percentage (3.73\%) of identified seeds of weed species A. fruticosa L. (Table 1). In comparison to some other seeds of weed species, such as Portulaca oleracea, Brassica rapa and Amaranthus retroflexus, in soil weed seed bank at locality Futog, identified seeds of weed species A. fruticosa L. had significantly lower germination.

On the studied locality Šangaj in the Danube coastal zone, the total of 14 weed species were identified: Amorpha fruticosa, Stellaria media, Amaranthus retroflexus, Ambrosia artemisiifolia, Urtica dioica, Brassica rapa, Mentha arvensis, Solanum nigrum, Portulaca oleracea, Polygonum aviculare, Polygonum laphatifolium, Trifolium repens,
Setaria glauca and Rumex crispus. In the first two layers of $0-10 \mathrm{~cm}$ and $10-20 \mathrm{~cm}$, the highest numbers of weed species seeds were identified, and seeds of $A$. fruticosa L. were found only in the first two layers on the first locality. In the first layer, 1,595 seeds $/ \mathrm{m}^{2}$ of weed species A. fruticosa L. were identified (Fig. 2). On the sampling locality Šangaj, the average numbers of A. fruticosa plants established were 3.14 plants $/ \mathrm{m}^{2}$ aged older than two years and 14.12 plants $/ \mathrm{m}^{2}$ aged of 1-2 years. The mostly distributed seeds were seeds of these weed species: Amorpha fruticosa, Stellaria media, Amaranthus retroflexus, Ambrosia artemisiifolia, Urtica dioica and Portulaca oleracea. Cardina et al. [20] have established that weed seed density in arable soils is always composed of several dominant weed species in a higher number.

The highest average deviation in relation to the average numbers of seeds showed the variation coefficient for weed species Brassica rapa, Solanum nigrum, Polygonum aviculare, Polygonum laphatifolium, Setaria glauca and Rumex crispus, while the average deviation showed the variation coefficient for weed species Portulaca oleracea. Looking at the total numbers of identified seeds of weed species, it can be perceived that a reduction in the numbers of seeds occurs with increasing of depth. In percentages, total germination of the identified seeds

Table 1 Statistical data processing by standard deviation and variation coefficient at locality Futog.

\begin{tabular}{|c|c|c|c|c|c|c|c|}
\hline \multirow{2}{*}{ Weed species } & \multicolumn{3}{|c|}{$\begin{array}{c}\text { No. of weed seeds in samples at } \\
\text { different soil depths }\end{array}$} & \multirow{2}{*}{$\begin{array}{l}\text { Arithmetic mean } \\
(0-30 \mathrm{~cm})\end{array}$} & \multirow{2}{*}{$\begin{array}{l}\text { Standard } \\
\text { deviation }\end{array}$} & \multirow{2}{*}{$\begin{array}{l}\text { Coefficient } \\
\text { of variation }\end{array}$} & \multirow{2}{*}{$\begin{array}{l}\text { Germination } \\
(\%)\end{array}$} \\
\hline & $0-10 \mathrm{~cm}$ & $10-20 \mathrm{~cm}$ & $20-30 \mathrm{~cm}$ & & & & \\
\hline Amaranthus retroflexus & 16 & 8 & 3 & 9 & 5.35 & 59.49 & 6.85 \\
\hline Amorpha fruticosa & 24 & 13 & 4 & 13.67 & 8.18 & 59.84 & 3.73 \\
\hline Brassica rapa & 8 & 0 & 0 & 2.67 & 3.77 & 141.42 & 8.77 \\
\hline Mentha arvensis & 3 & 3 & 0 & 2 & 1.41 & 70.71 & 0 \\
\hline Portulaca oleracea & 0 & 14 & 7 & 7 & 5.72 & 81.65 & 11.23 \\
\hline Rumex crispus & 0 & 4 & 0 & 1.33 & 1.89 & 141.42 & 0 \\
\hline Setaria glauca & 0 & 3 & 0 & 1 & 1.41 & 141.42 & 1.57 \\
\hline Solanum nigrum & 0 & 5 & 0 & 1.67 & 2.36 & 141.42 & 2.93 \\
\hline Stellaria media & 56 & 37 & 4 & 32.33 & 21.48 & 66.44 & 3.38 \\
\hline Trifolim repens & 0 & 3 & 8 & 3.67 & 3.30 & 90.00 & 0 \\
\hline Urtica dioica & 16 & 5 & 2 & 7.6 & 6.02 & 78.50 & 3.93 \\
\hline Total & 120 & 93 & 51 & 88 & & & \\
\hline
\end{tabular}




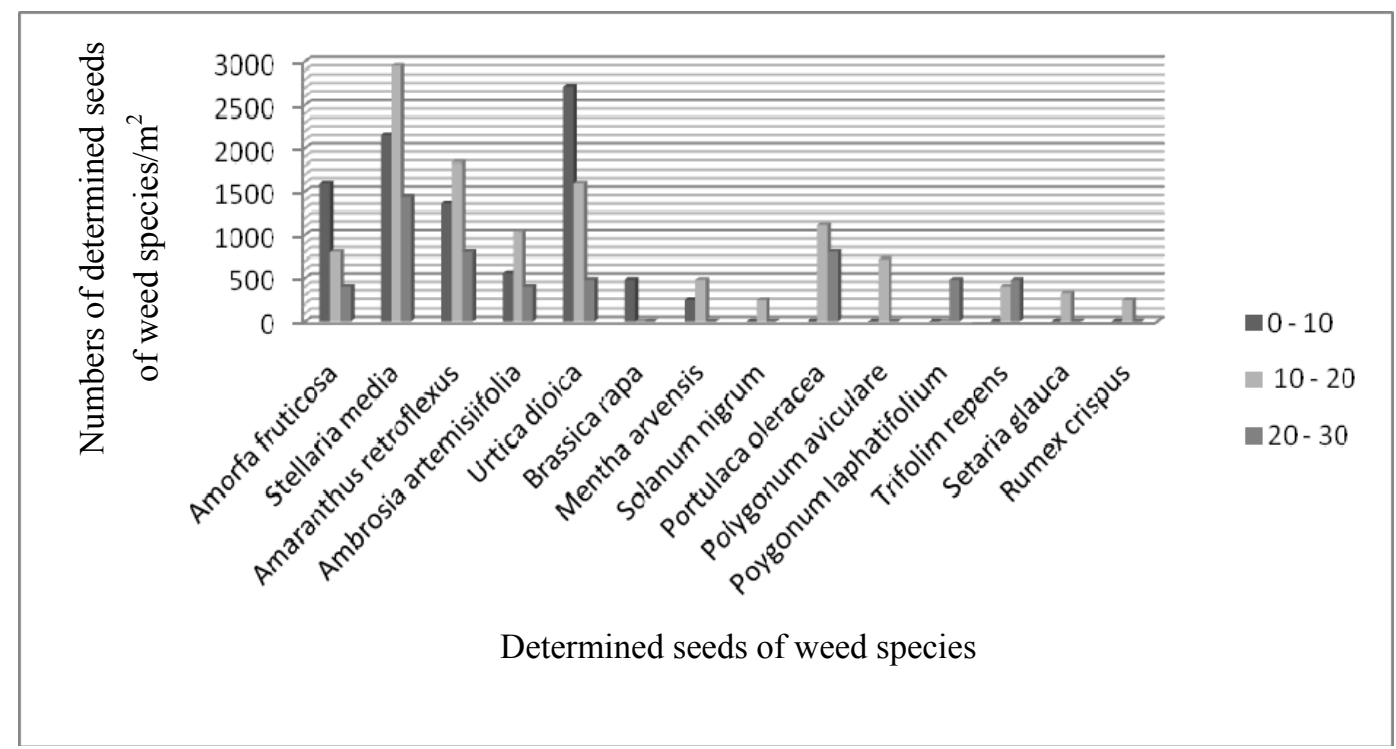

Fig. 2 The total numbers of weed species seeds $/ \mathrm{m}^{2}$ on locality Šangaj.

Table 2 Statistical data processing by standard deviation and variation coefficient on locality Šangaj.

\begin{tabular}{|c|c|c|c|c|c|c|c|}
\hline \multirow[t]{2}{*}{ Weed species } & \multicolumn{3}{|c|}{$\begin{array}{l}\text { No. of weed seeds in samples from } \\
\text { different soil depths }\end{array}$} & \multirow{2}{*}{$\begin{array}{l}\text { Arithmetic } \\
\text { mean } \\
(0-30 \mathrm{~cm})\end{array}$} & \multirow{2}{*}{$\begin{array}{l}\text { Standard } \\
\text { deviation }\end{array}$} & \multirow{2}{*}{$\begin{array}{l}\text { Coefficient } \\
\text { of variation }\end{array}$} & \multirow{2}{*}{$\begin{array}{l}\text { Germination } \\
(\%)\end{array}$} \\
\hline & $0-10 \mathrm{~cm}$ & $10-20 \mathrm{~cm}$ & $20-30 \mathrm{~cm}$ & & & & \\
\hline Amorpha fruticosa & 20 & 10 & 5 & 11.67 & 6.24 & 53.45 & 3.26 \\
\hline Stellaria media & 27 & 37 & 18 & 27.33 & 7.76 & 28.39 & 5.20 \\
\hline Amaranthus retroflexus & 17 & 23 & 10 & 16.67 & 5.31 & 31.87 & 7.23 \\
\hline Ambrosia artemisiifolia & 7 & 13 & 5 & 8.33 & 3.40 & 40.79 & 2.41 \\
\hline Urtica dioica & 34 & 20 & 6 & 20.00 & 11.43 & 57.15 & 6.67 \\
\hline Brassica rapa & 6 & 0 & 0 & 2.00 & 2.83 & 141.42 & 3.76 \\
\hline Mentha arvensis & 3 & 6 & 0 & 3.00 & 2.45 & 81.65 & 1.26 \\
\hline Solanum nigrum & 0 & 3 & 0 & 1.00 & 1.41 & 141.42 & 0 \\
\hline Portulaca oleracea & 17 & 14 & 10 & 13.67 & 2.87 & 20.98 & 9.33 \\
\hline Polygonum aviculare & 0 & 9 & 0 & 3.00 & 4.24 & 141.42 & 0 \\
\hline Polygonum laphatifolium & 0 & 0 & 6 & 2.00 & 2.83 & 141.42 & 0 \\
\hline Trifolim repens & 0 & 5 & 6 & 3.67 & 2.62 & 71.58 & 1.49 \\
\hline Setaria glauca & 0 & 4 & 0 & 1.33 & 1.89 & 141.42 & 0 \\
\hline Rumex crispus & 0 & 3 & 0 & 1.00 & 1.41 & 141.42 & 0 \\
\hline Total & 131 & 147 & 66 & 114.67 & & & \\
\hline
\end{tabular}

is in range of $1.26 \%$ for weed species Mentha arvensis to the maximum $9.33 \%$ for weed species Portulaca oleracea (Table 1). The numbers of potential plants in the subsequent vegetation on the locality Šangaj from the total number 2,792 seeds $/ \mathrm{m}^{2}$ were 91 plants $/ \mathrm{m}^{2}$, which was based on germination percentage $(3.26 \%)$ of A. fruticosa L. seeds (Table 2). Although these species are perennial, they almost promote the sexual reproduction compared to the vegetative reproduction, have a considerably high seed production as well as good vegetative growth and can greatly contribute to increasing this similarity [21]. Compared to some other weed species, such as Stellaria media, Amaranthus retroflexus, Urtica dioica and Portulaca oleracea, on the locality Šangaj soil weed seed bank, the species A. fruticosa L. had significantly lower germination of determined seeds.

Results of Ref. [22] suggest that weed seed bank is composed of several dominant weed species, but Amaranthus sp. has always been one of the dominant 
species, as it is shown in this study on both localities.

\section{Conclusions}

On locality Futog, the total numbers of seeds of weed species $A$. fruticosa was $3,270 / \mathrm{m}^{2}$ in all three soil depths. The largest number of weed species was determined in the first two layers, along with the fact that it is a flood-prone land on which the seeds of the weed species are harder to retain on the surface layers. In case of a flood, keeping the seeds on the surface layer of the Danube coastal zone represents potential risk for dispersal of weed species seeds on arable land. By translocation of the surface layer, weed species $A$. fruticosa becomes a problem on arable land or in their immediate vicinity. On studied localities, in case of flood, this potential of $A$. fruticosa seed may cause great problems. On these localities, seeds were retained on the surface soil layer. At locality Šangaj, a total numbers of seeds of weed species $A$. fruticosa on depth of 0-30 cm were $2,792 / \mathrm{m}^{2}$. A total numbers of seeds of weed species $/ \mathrm{m}^{2}$ on locality Futog and Šangaj were 19,060 , i.e., $27,440 \mathrm{seeds} / \mathrm{m}^{2}$. The results of the study present that the potential weed development to a great extent can limit free water flow on the canal network as well as the infestation of forests in the Danube coastal zone.

\section{References}

[1] Tucović, A., and Isajev, V. 2001. "Characteristics and Variability of Amorpha fruticosa L. Seedlings-Weed Species of Floodplain Habitats." Acta Therbologica 9 (1): 101-11. (in Serbian)

[2] Botta-Dukat, Z. 2008. "Invasion of Alien Species to Hungarian (Semi-) Natural Habitats.” Acta Botanica Hungarica 50: 219-27.

[3] Dumitrascu, M., Grigorescu, I., Nastase, M., Dragota C., and Kucsicsa, G. 2010. "The Main Environmental Driving Forces of the Invasive Plant Species in the Romanian Protected Areas." In Proceedings of BALWOIS Conference on Water Observation and Information Systems for Decision Support, 1-12.

[4] Fargione, J. E., and Tilman, D. 2005. "Diversity Decreases Invasion via Both Sampling and Complementary Effects.” Ecology Letters 8: 604-11.

[5] Anastasiu, P., Negrean, G., Bas, C., Sirbu, C., and Oprea,
A. 2007. "A Preliminary Study on the Neophytes of Wetlands in Romania." Neobiota 7 (18): 181-92.

[6] Steinmann, H. H., and Klingebiel, L. 2004. "Secondary Dispersal, Spatial Dynamics and Effects of Herbicides on Reproductive Capacity of a Recently Introduced Population of Bromus sterilis in an Arable Field." Weed Res. 44 (5): 388-96.

[7] Blumenthal, D. M., and Jordan, N. R. 2001. "Weeds in Field Margins: A Spatially Explicit Simulation Analysis of Cirsium arvense Population Dynamics." Weed Science 49: 509-19.

[8] Anderson, R. L., Tanaka, D. L., Black, A. L., and Schweizer, E. E. 1998. "Weed Community and Species Response to Crop Rotation Tillage and Nitrogen Fertility." Weed Technol. 12 (3): 531-6.

[9] Konstantinović, B. 2011. Fundamentals of Herbology and Herbicides. Serbia: Faculty of Agriculture, University of Novi Sad, 419. (in Serbian)

[10] Vitousek, P. M. 1994. "Beyond Global Warming: Ecology and Global Change." Ecology 75: 1861-76.

[11] Rejmanek, M., Richardson, D. M., and Pysek, P. 2005. "Plant Invasions and Invasibility of Plant Communities." In Vegetation Ecology, edited by Van der Maarel, E. Oxford, UK: Blackwell Science, 332-55.

[12] Pino, J., Segui, J. M., and Alvarez, N. 2006. "Invasibility of Four Plant Communities in the Llobregat Delta (Catalonia, NE of Spain) in Relation to Their Historical Stability." Hydrobiologia 570 (1): 257-63.

[13] Pysek, P., and Prach, K. 1993. "Plant Invasions and the Role of Riparian Habitats: A Comparison of Four Species Alien to Central Europe." J. Biogeo. 20 (4): 413-20.

[14] Zedler, J. B., and Kercher, S. 2004. "Causes and Consequences of Invasive Plants in Wet-Lands: Opportunities, Opportunists and Outcomes." Critical Reviews in Plant Sciences 23 (5): 431-52.

[15] Pysek, P., Richardson, D. M., Rejmanek, M., Webster, G. L., Williamson, M., and Kirschner, J. 2004. "Alien Plants in Checklists and Floras: Towards Better Communication between Taxonomists and Ecologists." Taxon 53 (1): 131-43.

[16] Skender, A. 1998. "Seeds and Fruits Agricultural Crops and Weeds on Croatian Territory." Faculty of Agriculture, University of Osijek. Accessed May 12, 2015. http://ezop-antikvarijat.hr/foto1.php?productID=19690.

[17] Conn, J. 1987. "Effects of Tillage and Straw Management on Alaskan Weed Vegetation: A Study on Newly Cleared Land.” Soil Tillage Res. 9 (3): 275-85.

[18] Sharatt, B. 1998. "Barley Yield and Evapotranspiration Governed by Tillage Practices in Interior Alaska." Soil Tillage Res. 46 (3-4): 225-9.

[19] Du Croix-Sissons, M. J., Van Acker, R. C., Derksen, D. A., and Thomas, A. G. 2000. "Depth of Seedling Recruitment 
of Five Weed Species Measured in Situ in Conventionaland Zero-Tillage Fields." Weed Sci. 48 (3): 327-32.

[20] Cardina, J., Regnier, E., and Harrison, K. 1991. "Long-Term Tillage Effect on Seed Bank in Three Ohio Soils." Weed Science 39 (2): 186-94.

[21] Hui, L., and Keqin, W. 2006. "Soil Seed Bank and
Aboveground Vegetation within Hillslope Vegetation Restoration Sites in Jinshajing Hot-Dry River Valley." Acta Ecologica Sinica 26 (8): 2432-42.

[22] Uremis, A., Christensen, S., and Simmelsgaard, S. 2002. "Spatial Correlation between Weed Species Densities and Soil Properties." Weed Research 42 (1): 26-38. 